\title{
Development of Regenerative Braking Concept for Electric Vehicle Enhanced with Bidirectional Converter
}

\author{
M. Kavitha ${ }^{1}$, V. Elanangai ${ }^{2}$, S. Jayaprakash ${ }^{3}$, V. Balasubramanian ${ }^{4}$ \\ ${ }^{1,2,3}$ Department of Electrical and Electronics Engineering, Sathyabama Institute of Science and Technology, India \\ ${ }^{4}$ Department of Electrical and Electronics Engineering, St.Joseph's College of Engineering, India
}

\begin{tabular}{l}
\hline Article Info \\
\hline Article history: \\
Received May 14, 2018 \\
Revised Jul 29, 2018 \\
Accepted Sep 10, 2018 \\
\hline
\end{tabular}

Keyword:

Bidirectional

DC-DC converter

Regenerative Braking

\begin{abstract}
Due to the increasing concern for environment protection and the uncertainty about oil reserves, nowadays electricity is playing a key role as an alternative energy source in the automotive sector. In this paper, non isolated bidirectional converter is used for electric vehicle application during regenerative braking process. During motoring operation, the converter supplies energy to motor through battery. In regenerative braking action, the converter supplies the available back emf to charge the battery. The recycled energy is effectively stored in the battery. The simulation is carried out in MATLAB/Simulink. The worthiness of simulation is illustrated experimentally by developing a prototype. The simulation and experimental results are presented in this paper.
\end{abstract}

Copyright $(0) 2018$ Institute of Advanced Engineering and Science. All rights reserved.

\section{Corresponding Author:}

M. Kavitha,

Department of Electrical and Electronics Engineering,

Sathyabama Institute of Science and Technology(Deemed to be University),

Chennai-600119, Tamil Nadu, India.

Email: kaveem@gmail.com

\section{INTRODUCTION}

Hybrid power sources combining various combinations of fuel cell, solar and battery are popular in automotive systems, renewable energy conversion systems and in the fuel cell-based residential systems. Due to the increasing concern for environment protection and the uncertainty about oil reserves, nowadays electricity is playing a key role as an alternative energy source in the automotive sector. An Electric Vehicle (EV) significantly reduces the daily traveling costs, because the maintenance and operation costs of these vehicles are lower than the conventional ones [1]-[3]. Therefore, for electric vehicle application, bidirectional converter is used between battery and motor. In this case, proper battery management is required [4]-[6].

Non- isolated bidirectional converter have been used for isolation [7] and other several non isolated converters were introduced in [8]-[10]. The DC-DC converter with switched type capacitor is proposed in [11]-[12], but it requires more capacitors. The DC-DC converter with coupled inductor were introduced in [13]-[19], but it produced current ripple.

In electric vehicle, the electrical energy is extracted from rotational energy by using proper converter with suitable charging and discharging profiles. Hence in this paper, two half bridge converters are connected together and capable of transferring energy both in motoring and regenerative braking action. Section 2 describes the principle and modes of operation of bidirectional converter. The simulation results and hardware implementation are described in Section 3 and 4 respectively. 


\section{BIDIRECTIONAL DC-DC CONVERTER}

Figure 1 represents the bidirectional DC-DC converter which consists of two half bridge cells which are connected through an auxillary capacitor $\mathrm{Ca}$ and inductor $\mathrm{L}_{\mathrm{a}}$ [20]. $\mathrm{M}_{1}$ and $\mathrm{M}_{2}$ are the low voltage side switches which operate under duty cycle 1-D and D respectively. $\mathrm{M}_{3}$ and $\mathrm{M}_{4}$ are the high voltage side switches which operate under duty cycle $1-\mathrm{D}$ and $\mathrm{D}$ respectively. $\mathrm{L}_{\mathrm{f}}$ is the filter inductance. $\mathrm{C}_{1}$ and $\mathrm{C}_{2}$ are output capacitors connected in series to produce high voltage gain.

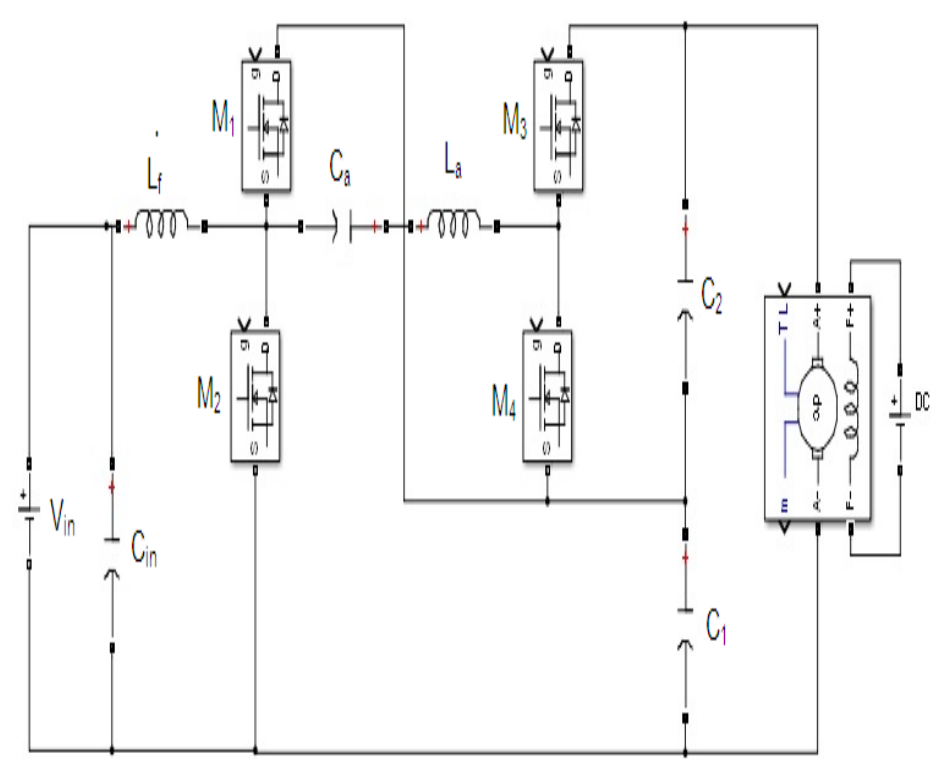

Figure 1. Bidirectional DC-DC converter using two half bridge cells

There are three modes of operation. During motoring action, the voltage of the battery is stepped up and delivers to the motor. During braking action, the back emf is used for charging the battery and thus machine act as generator.

\subsection{Mode 1}

In this mode, switches $M_{2}$ and $M_{4}$ are off and switch $M_{1}$ is $O N$ and $M_{3}$ is in switching mode. In this mode, the converter step up the required voltage to motor. This mode comes in to operation during motoring action.

\subsection{Mode 2}

In this mode, switches $\mathrm{M}_{2}$ and $\mathrm{M}_{4}$ are off and switch $\mathrm{M}_{1}$ is $\mathrm{ON}$ and $\mathrm{M}_{3}$ is in switching mode. In this mode, the DC machine voltage is stepped down and given to the battery. This mode comes in to operation when the back emf is greater than voltage of the battery during braking action.

\subsection{Mode 3}

In this mode, switches $\mathrm{M}_{1}$ and $\mathrm{M}_{4}$ are off, switch $\mathrm{M}_{3}$ is $\mathrm{ON}$ and $\mathrm{M}_{2}$ is in switching mode. This mode comes in to operation only when back emf is less than voltage across the battery during braking action.

\section{SIMULATION RESULTS}

Figure 2 represents the simulation circuit diagram of bidirectional DC-DC converter with DC motor on load side through auxillary capacitor $C_{a}=30 \mu \mathrm{F}$ and inductor $L_{a}=12 \mu \mathrm{H}$. The filter inductance $L_{f}=37.5 \mu \mathrm{H}$ is used. The output capacitors $\mathrm{C}_{1}=30 \mu \mathrm{F}$ and $\mathrm{C}_{2}=30 \mu \mathrm{F}$ are connected in series across the motor to achieve high voltage gain. Initially the converter step up the input voltage from $6 \mathrm{~V}$ to $18 \mathrm{~V}$ and this voltage is supplied to the motor. The switching frequency of $50 \mathrm{kHz}$ is used. At $4.5 \mathrm{sec}$ the input voltage is reduced to $1 \mathrm{~V}$ and the converter operates in braking mode. In this braking mode, the back emf of $0.6 \mathrm{~V}$ generated by the DC machine is stored in the battery. 


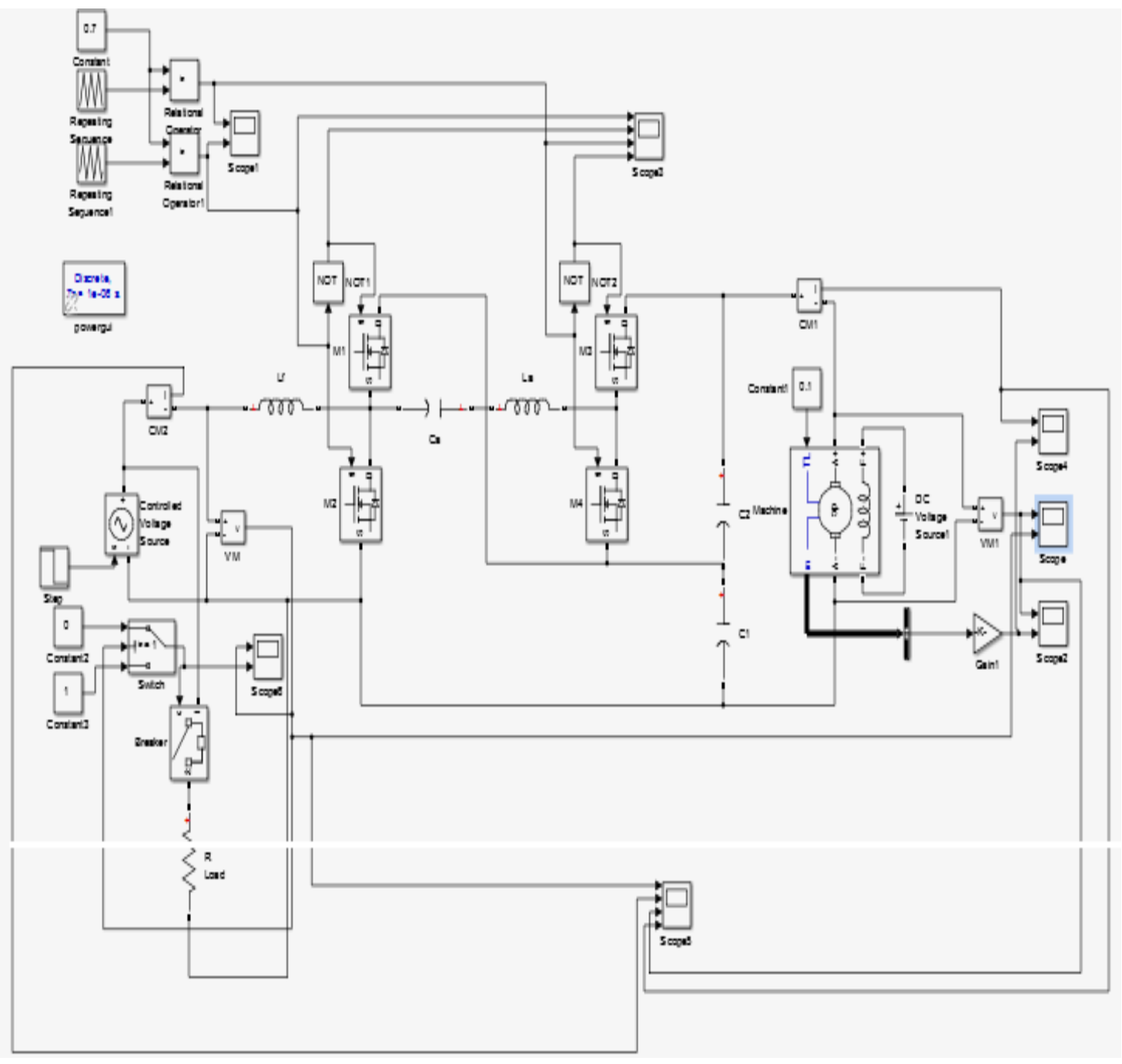

Figure 2. Simulation Diagram of Passive Clamp based DC-DC converter fed by Photovoltaic Module

Figure 3 shows the input voltage waveform during motoring action and in braking action. Figure 4 shows the input-output voltage and current waveform of the converter. Figure 5 shows that during motoring action, $18 \mathrm{~V}$ is supplied to the motor and during braking mode, about $0.6 \mathrm{~V}$ is generated by the DC machine.

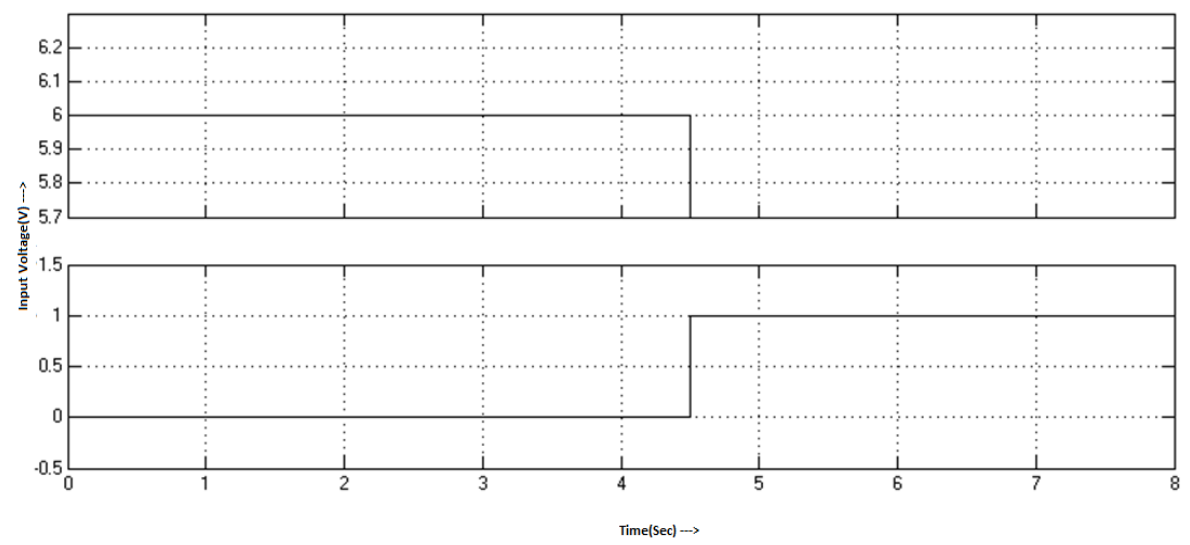

Figure 3. Input voltage waveform 

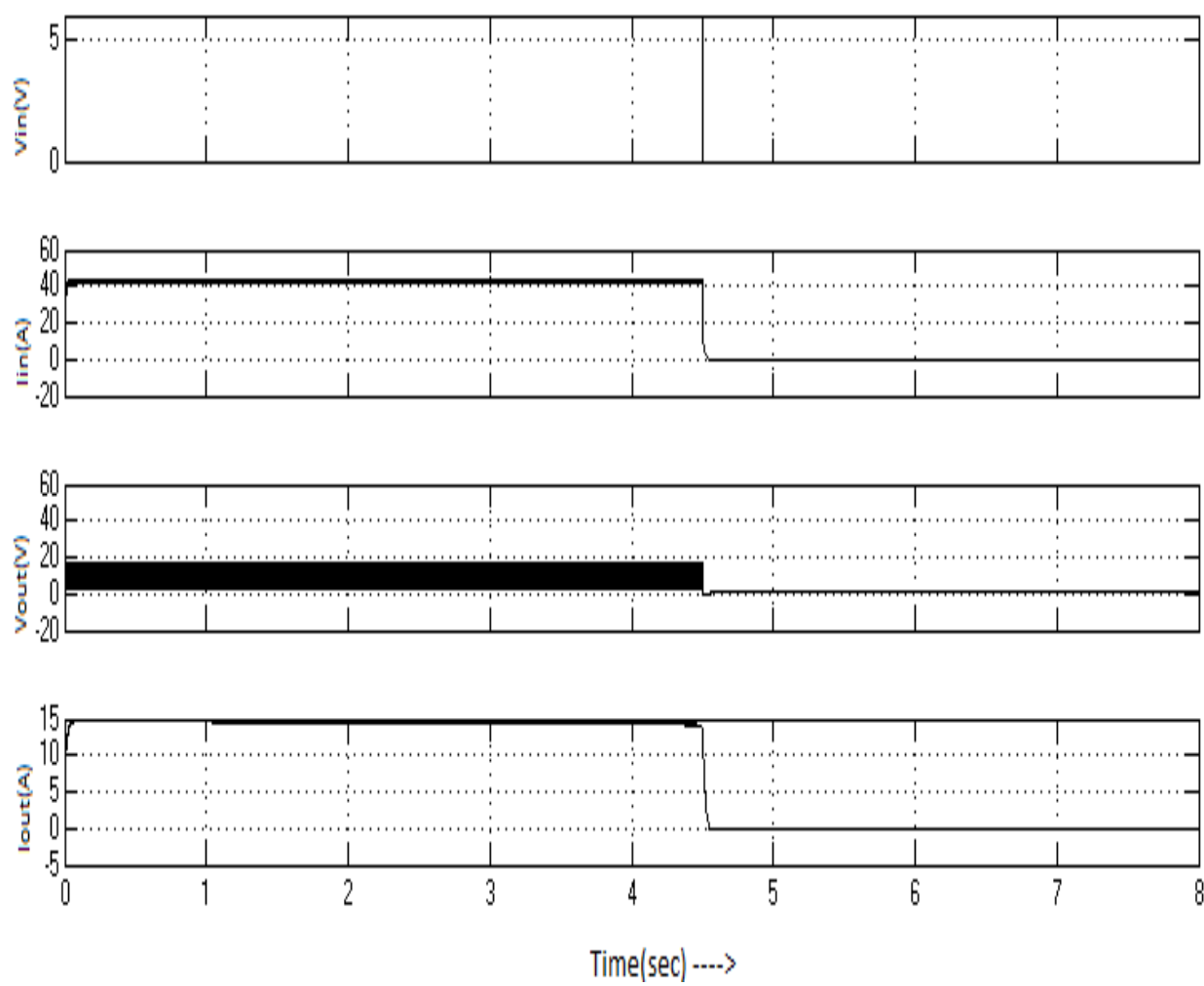

Figure 4. Input-output voltage and current waveform
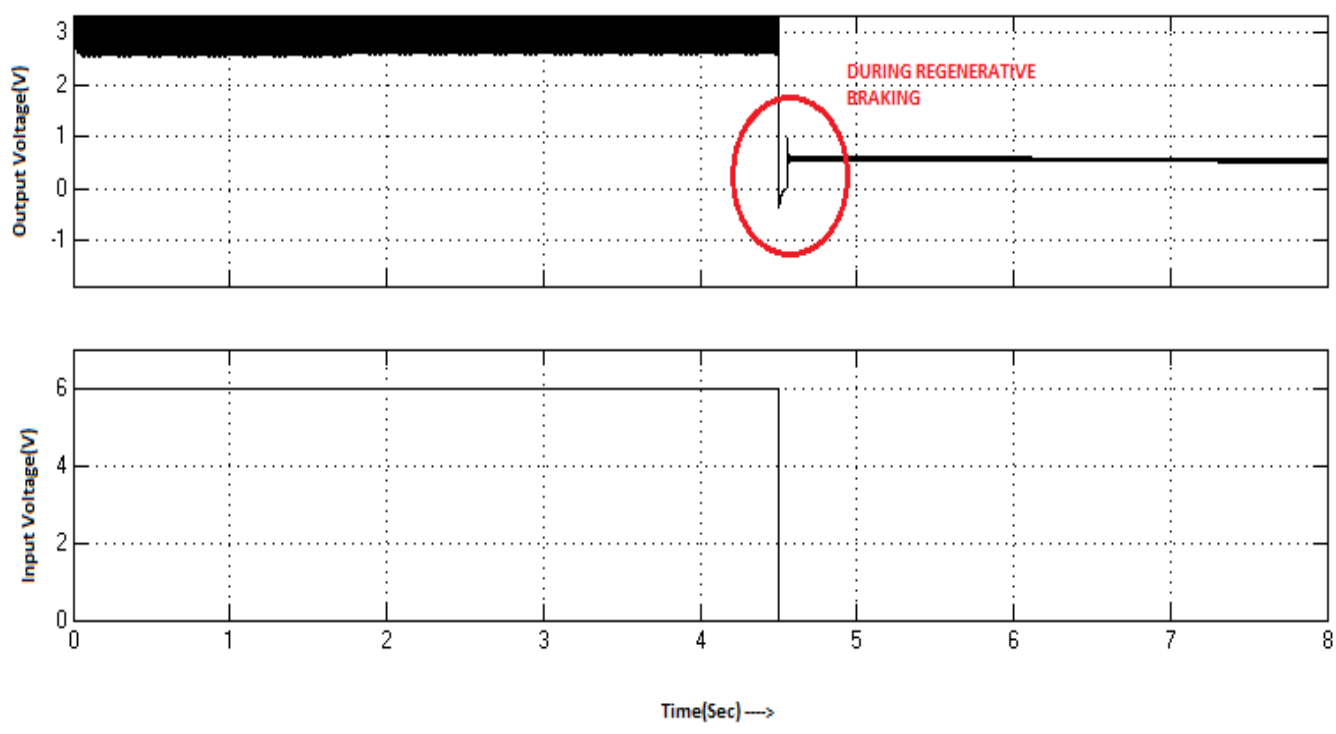

Figure 5. Output voltage during regenerative braking

\section{HARDWARE IMPLEMENTATION}

The worthiness of simulation results are validated by prototype. Figure 6 shows the experimental setup. The hardware consists of step down transformer, rectifier, bidirectional converter, microcontroller, sensing unit and gate driver circuit. The $230 \mathrm{~V}$ AC supply is stepped down to $12 \mathrm{~V}$ AC by a step down transformer. The $12 \mathrm{~V}$ AC supply is converted in to DC by a bridge rectifier. The output of bridge rectifier is given to voltage regulator IC7805 to obtain constant 5V DC supply which is given to PIC16F887 microcontroller. The micro controller produces control signal for the bidirectional converter switches which is not sufficient to drive the switch. Therefore an optocoupler is used to produce required driving pulse for switch. The generated pulses are given to bidirectional converter switch. Output voltage of the converter 
depends on switching duty cycle. In forward mode of operation, the flow of energy is from battery to motor which turns the wheel of the vehicle providing kinetic energy to move. In this mode, input voltage of $6 \mathrm{~V}$ is stepped up to $12 \mathrm{~V}$ and supplied to flywheel motor of rating $12 \mathrm{~V}, 2 \mathrm{~A}, 1500 \mathrm{rpm}$. Figure 6 shows the speed of the motor. During braking action, when the input supply voltage is cut off, then the motor works as generator and produces back emf of $1.65 \mathrm{~V}$ which is stored in the battery as shown in Figure 7. So a good proportion of energy which was lost by braking is returned to the battery and can be reused.

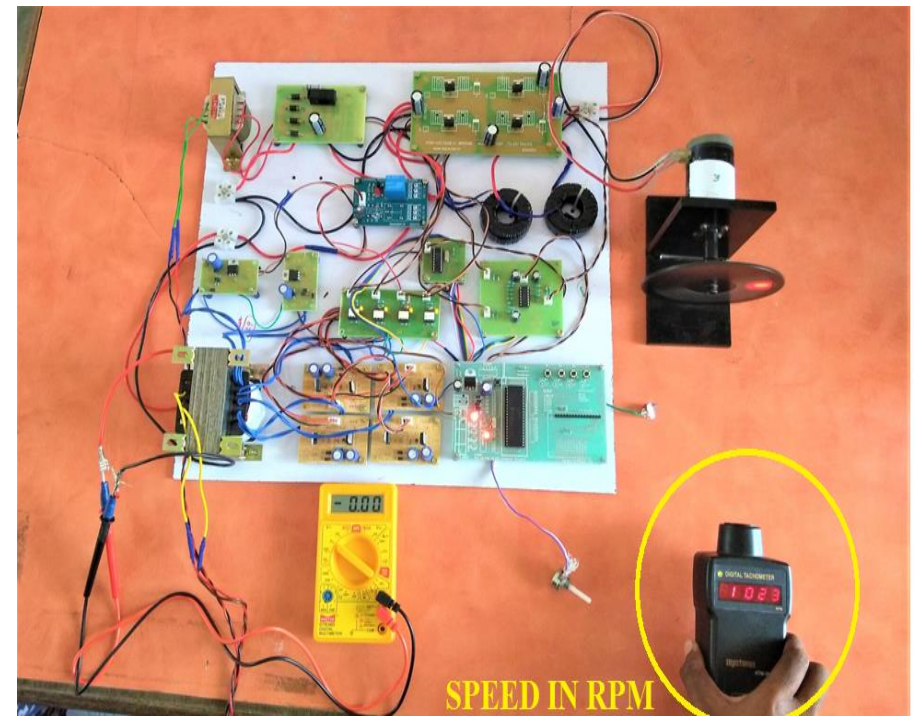

Figure 6. Speed of flywheel DC motor

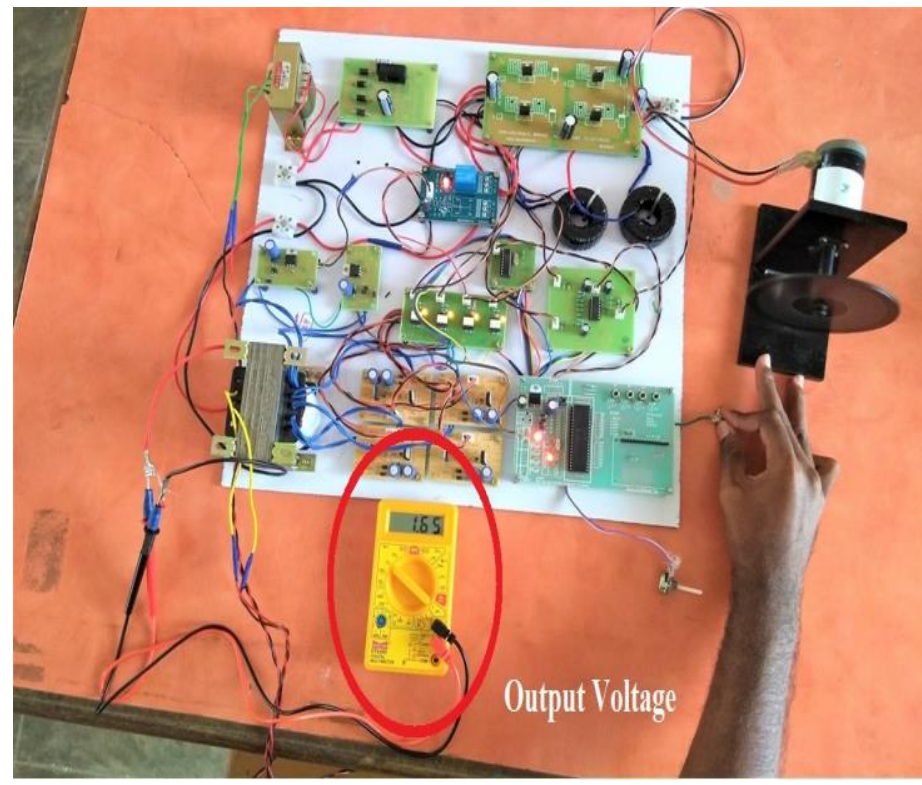

Figure 7. Output voltage during braking action

\section{CONCLUSION}

The non- isolated bidirectional converters with two half bridge cells are used for electric vehicle application. During regenerative braking mode, the bidirectional converter stores the energy to battery which was generated by DC machine. So a good proportion of energy which was lost by braking is returned to the battery and can be reused.

\section{REFERENCES}


[1] M. Ceraolo, et al., "A general approach to energy optimization of hybrid electric vehicles," IEEE Trans. Veh. Technol., vol/issue: 57(3), pp. 1433-1441, 2008.

[2] J. Bauman and M. Kazerani, "A comparative study of fuel-cell battery, fuel-cell-ultracapacitor, and fuel-cellbattery-ultracapacitor vehicles," IEEE Trans. Veh. Technol., vol/issue: 57(2), pp. 760-769, 2008.

[3] M. Kavitha and V. Sivachidambaranathan, "PV based high voltage gain Quadratic DC- DC Converter integrated with coupled inductor," International Conference on Computation of Power, Energy Information and Communication (ICCPEIC'16), pp. 607-612, 2016.

[4] M. Aamir, et al., "High-Gain Zero-Voltage Switching Bidirectional Converter With a Reduced Number of Switches," IEEE Trans. Circuits Syst. II, Express Briefs, vol/issue: 62(8), pp. 816-820, 2015.

[5] M. Uno and A. Kukita, "Bidirectional PWM converter integrating cell voltage equalizer using series-resonant voltage multiplier for seriesconnected energy storage cells," IEEE Trans. Power Electron., vol/issue: 30(6), pp. 3077-3090, 2015.

[6] Y. Hsieh, et al., "High-conversion-ratio bidirectional DC-DC converter with coupled inductor," IEEE Trans. Ind.Electron., vol/issue: 61(1), pp. 210-222, 2014

[7] F. L. Tofoli, et al., "Survey on non-isolated high-voltage step-up dc-dc topologies based on the boost converter," IET Power Electron., vol/issue: 8(10), pp. 2044-2057, 2015.

[8] B. L. Narasimharaju, et al., "Design and analysis of coupled inductor bidirectionalDC-DC convertor for highvoltage diversity applications," IET. Power Electron., vol/issue: 5(7), pp. 998-1007, 2012.

[9] M. N. Gitau, et al., "Analysis and Design of a Single-Phase Tapped-Coupled-Inductor Boost DC-DC Converter," J.Power Electron., vol/issue: 13(4), pp. 636-646, 2013.

[10] J. Yao, et al., "Steep-gain bidirectional converter with a regenerative snubber," IEEE Trans. Power Electron., vol/issue: 30(12), pp. 6845-6856, 2015.

[11] C. C. Lin, et al., "Study of a non-isolated bidirectional DC-DC converter," IET Power Electron., vol. 6, pp. 30-37, 2013.

[12] H. P. Le, et al., "Design techniques for fully integrated switched-capacitor DC-DC converters," IEEE Trans. SolidState Circuits, vol/issue: 46(9), pp. 2120-2131, 2011.

[13] T. J. Liang, et al., "Analysis, design, and implementation of a bidirectional double-boost DC-DC converter," IEEE Trans. Industry Applications, vol/issue: 50(6), pp. 3955-3962, 2014.

[14] V. Balasubramanian, et al., "Alleviate the voltage gain of high step-up DC to DC converter using quasi active switched inductor structure for renewable energy," Computation of Power, Energy Information and Commuincation (ICCPEIC), 2017 International Conference on, pp. 835-841, 2017.

[15] M. Al Mamun, et al., "High Gain Non Isolated DC-DC Step-up Converters Integrated with Active and Passive Switched Inductor Networks," International Journal of Power Electronics and Drive Systems (IJPEDS), vol/issue:9(2), pp. 679-689, 2018.

[16] E. Dimopoulos and S. M. Nielsen, "A Tapped-Inductor Buck-Boost Converter for a Dielectric ElectroActive Polymer Generator," Proc. 29th IEEE Appl. Power Electron. Conf. Expo., pp. 3125-3131, 2014.

[17] M. Kavitha and V. Sivachidambaranathan, "Power factor correction in fuzzy based brushless DC motor fed by bridgeless buck boost converter," Computation of Power, Energy Information and Commuincation (ICCPEIC), 2017 International Conference on, pp. 549-553, 2017.

[18] J. K. Abed, "Smart Monitoring System of DC to DC Converter for Photovoltaic Application," International Journal of Power Electronics and Drive Systems (IJPEDS), vol/issue: 9(2), pp. 722-729, 2018.

[19] M. Kavitha and V. Sivachidambaranathan, "Comparison of Different Control Techniques for Interleaved DC-DC Converter," International Journal of Power Electronics and Drive Systems (IJPEDS), vol/issue: 9(2), pp. 641-647, 2018..

[20] H. Jeong, et al., "Analysis, Design, and Implementation of a High Gain Soft-switching Bidirectional DC-DC Converter with PPS Control," IEEE Transactions on Power Electronics, pp. 4807-4816, 2017.

\section{BIOGRAPHIES OF AUTHORS}

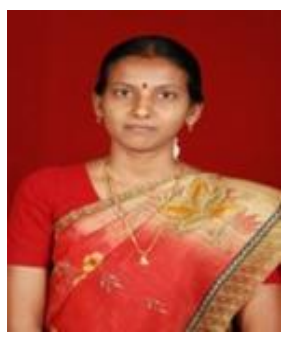

M. Kavitha has received her B.E degree in Electrical and Electronics Engineering from Bharathiyar University, Tamilnadu, India in 2000 and M.E degree in Power Systems Engineering from Anna University, Tamilnadu, India in 2012. She is pursuing her Ph.D under the faculty of Electrical and Electronics Engineering at Sathyabama Institute of Science and Technology from 2014. Her research interest includes Renewable Energy sources, Energy storage system, Fuzzy logic controller, Artificial Neural network and Power Electronic Converters. 


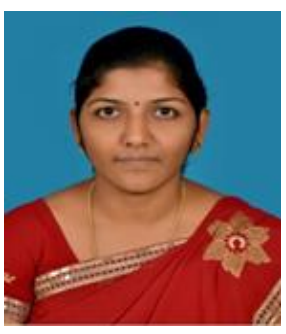

V. Elanangai has received her B.E degree in Electrical and Electronics Engineering from St. Peters Engineering College, Tamilnadu, India in 2003 and M.Tech degree in VLSI Design from Sathyabama University, Tamilnadu, India in 2006. She is pursuing her Ph.D under the faculty of Electronics and Communication Engineering at Sathyabama Institute of Science and Technology from 2016. Her research interest includes Image Processing, VLSI Design, Fuzzy logic, Artificial Neural Network.

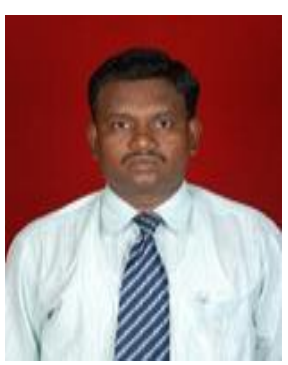

S. Jayaprakash has completed Diploma in Electrical and Electronics Engineering, DOTE, Chennai, in 1996, B.E. Degree in Electrical and Electronics from the University of Madras in 1999 and M.E. Degree in Power Electronics and Industrial Drives from Sathvabama University in 2007. Presently he is pursuing Ph.D. programme at Sathyabama Institute of Science and Technology. His research interests include Power Electronic Converters, PWM Technique in Power Electronics and other related topics.

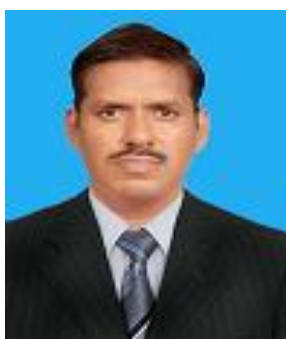

V. Balasubramanian has received his B.E degree in Electrical and Electronics Engineering from Government College of Engineering, Salem, Tamilnadu, India in 1999 and M.E degree in Power Electronics And Industrial Drives from Sathyabama University in the year of 2015, Tamilnadu, India in 2015. His research interest includes Inverter, power DC-DC converter, green energy, 